\title{
sciendo
}

10.2478/ewcp-2019-0004

\section{Give Us This Day Our Daily Absurd, As We Also Have Given It to Our Absurd-mongers! One Look at the Absurd in Romanian Culture}

\author{
ESTELLA CIOBANU \\ Ovidius University of Constanţa, Romania
}

\begin{abstract}
An unpublished piece of prose in the style of Romanian writer Urmuz has rekindled my interest in absurdist writings and/or absurd cases which, in Romanian culture, are associated with the likes of Urmuz, Caragiale or Ionesco. I will ponder here, with the aid of the aforementioned authors and also by comparing their work with Lewis Carroll's, the absurdist spirit of certain Romanian literary and dramatic pieces, or only of certain scenes therein, to propose a typology of the absurd as distinct from satire (the latter often a companion piece to the former). Mine is an investigation that crisscrosses texts, cultures and ages more than it offers an in-depth analysis by recourse to concepts and theories; asks questions more than it offers answers; plays more than it does sober research; and laughs - lest it should weep.
\end{abstract}

Keywords: absurd, uncanny (unheimlich), Urmuz, Eugène Ionesco, I. L. Caragiale, Ion Creangă, Lewis Carroll, J. L. Borges

Într-o zi Mătuşa Mioara se duse la piaţă să cumpere legume pentru a face plăcintă de piţigoi pitic. La o tarabă stătea Herda Ionescu, vânzând carne de piţigoi omeneşti-uriaşi, cartofi, raţă la cuptor, raţă coaptă la $10^{\circ} \mathrm{C}$ şi ţigări de 
propagandă la 1 leu bucata. Mătuşa Mioara se uită la carne, apoi la cartofi, apoi la raţa coaptă dar strigă la Ionescu Herda în gura mare să-i pună într-o pungă 100 de ţigări de propagandă. ${ }^{1}$ Herda îi spuse că ţigările nu sunt de vânzare pentru mătuşi în special. Atunci Mătuşa Mioara se duse la poliţie şi depuse o plângere:

Herda Ionescu nu vinde ţigări la mătuşi, în special! De aceea nici nu o să mai plătesc cartofii pe care îi voi ciordi de la Herda.

[One day Aunt Mioara went to the market to buy vegetables to bake a dwarf blue tit pie. Behind one stand stood Herda Ionescu, selling human-sized blue tit, potatoes, duck casserole, duck baked at $10^{\circ} \mathrm{C}$ and propaganda cigarettes at 1 Leu apiece. Aunt Mioara scrutinised the meat, then the potatoes, then the baked duck, but yelled at Ionescu Herda at the top of her voice to pack her 100 propaganda cigarettes. Herda told her that the cigarettes are not for sale for aunts in particular. On hearing this, Aunt Mioara went to the police to file a complaint:

Herda Ionescu won't sell cigarettes to aunts, in particular! That's why I'm not going to pay for the potatoes that I'll pilfer from her.]

This is not a newly unearthed piece by Urmuz or his likes. Nor am I the author, either. It is (the beginning of) a text penned by an individual not even aspiring to become a writer. ${ }^{2}$ To me, "Aunt Mioara at the Marketplace" conjures the best of the absurd, naïve or ridiculous featured in Romanian writings. This article essays a modest typology of the absurd as illustrated in Romanian (mostly fictional) texts contrasted with foreign ones. (As if the absurd could be circumscribed within reason-framed categories...). I am interested in the absurdist vein which shoots through fiction and non-fiction alike, without claiming that I (or anyone) could thereby 
penetrate the collective Romanian mindset or some (non-) Romanian writers' fondness for writerly games that verge on the absurd.

For once I will resume quoting Sonja's full text:

${ }^{3}$ Când Mătuşa Mioara ajunse acasă, cu legumele luate din altă parte, începu să gătească plăcinta de piţigoi pitic. În cartea de bucate...

... INGREDIENTE:

- $\quad 3$ ochi de piţigoi pitici

- 2 mere

- $\quad-7$ ouă

- 12 cireşe

- -8 morcovi

- 5 banane

- 10 ceve [sic] plângăcioase

- brânză

- - subconştient de piţigoi

- - porumbel orb

- ardei slab

- - Grigore

- păr de capră turbată

- turtă de albuş

- piersicăruri $[s i c]$ de caise negre ${ }^{4}$

Mod de preparare:

- se ung ochii de piţigoi cu cremă de noapte şi se trântesc într-un bol umplut cu ${ }^{5}$ cele 7 ouă. Apoi tăiaţi morcovii şi treptat înverziţii [sic] în vopsea veche. Tăiaţi un picior de la porumbelul orb şi puneţi-1 laolaltă cu ingredientele preparate. Apoi discutaţi cu subconştientul de piţigoi unde este mâna lui Grigore. După toate acestea fierbeţi ingredientele şi striviţile [sic] în acelaşi bol cu ochii, ouăle ${ }^{6}$ etc şi $^{7}$ puneţi-le pe o bancă în parc pentru a se coace la soare. Apoi, peste trei săptămâni, duceţi-vă să o luaţi. 
Aşa a făcut şi Mătuşa Mioara, numai că, ei, i-a ieşit o brânză cu cinci picioare. ("Mătuşa Mioara la piaţă")

${ }^{3}$ [When Aunt Mioara got home, having bought her vegetables elsewhere, she started to prepare the dwarf blue tit pie.

In the cookery book...

... INGREDIENTS:

- -3 eyes of dwarf blue tit

- 2 apples

- $\quad-7$ eggs

- 12 cherries

- -8 carrots

- 5 bananas

- 10 crying ceve [sic]

- cheese

- - subconscious of blue tit

- - blind pigeon

- lean pepper

- - Gregory

- hair of rabid goat

- cake of egg whites

- peach-dish of black apricots ${ }^{4}$

Preparation:

- the blue tit eyes are covered with night cream and thrown [sic] into a bowl filled with ${ }^{5}$ the 7 eggs. Then chop up the carrots and gradually dye them green in old paint. Cut off one leg of the blind pigeon and add it to the already prepared ingredients. Then talk with the subconscious of blue tit where Gregory's hand is. Afterwards boil the ingredients and crush them in the bowl where you have the eyes, eggs ${ }^{6}$ etc. and $^{7}$ place them on a bench in the park to bake in the sun. ${ }^{8}$ Then, in three weeks' time, go to get it. 
So did Aunt Mioara too, only she got a five-legged cheese. ("Aunt Mioara at the Marketplace")

Piece of cake...

Sonja made several alterations to her text, yet the quantitatively most significant one actually suggests a qualitative "correction" of imagery in absurdist vein. The preparation stage reconsiders the early băgaţi-le la cu ("place them into the ov..." most likely oven), regarding the already crushed and mixed ingredients, to propose an unusual baking procedure. The startling outcome defies our empirical experience, yet it is fully in tune with the text's uncanny logic.'

Here is, for comparison, Urmuz (1883-1923). The second paragraph of The Funnel and Stamate: A Novel in Four Parts (Pâlnia şi Stamate. Roman în patru părţi, 1922) describes, after its first sentence, a living-room:

O masă fără picioare, la mijloc, bazată pe calcule şi probabilităţi, suportă un vas ce conţine esenţa eternă a "lucrului în sine," un căţel de usturoi, o statuetă ce reprezintă un popă (ardelenesc) ţinând în mână o sintaxă şi... 20 de bani bacşiş... Restul nu prezintă nicio importanţă. (Urmuz 76)

[A legless table right in the middle, based on probability calculus and supporting a vase containing eternal concentrate of the "thing in itself," a clove of garlic, the statuette of a priest (from Ardeal ${ }^{10}$ ) holding a book of syntax and... 20 cents for tips... the rest being without interest whatsoever. (Urmuz, Weird Pages np; trans. Deligiorgis)]

Urmuz's enumeration of the items on the table anticipates by two decades the implicit enumeration underpinning Jorge Luis Borges's fictitious animal taxonomy in "El idioma analítico de John Wilkins" (1942); Sonja's ingredient list echoes it through its unlikely juxtapositions. Borges mentions "a certain Chinese encyclopedia called the Heavenly Emporium of Benevolent Knowledge" (103) whose fourteen incommensurable categories overlap object language and metalanguage to humorous-absurd 
effect. The former language type identifies both real animal categories, e.g. (d) "suckling pigs" and (g) "stray dogs," and imaginary creatures, e.g. (e) "mermaids." To the latter language type belongs a taxonomic assortment of animals: (a) "those that belong to the emperor"; (b) "embalmed ones"; (c) "those that are trained"; (f) "fabulous ones"; (1) "etcetera"; and a self-reflexive category: (h) "those that are included in this classification" (103). Urmuz lacks categories, yet the incommensurable is the text's tenor.

Urmuz provides strange menus at many unexpected turns in his texts. Such is a passage in Algazy and Grummer (Algazy şi Grummer, 1928) which shows what can be consumed to quench one's actual or metaphorical hunger and even solitude:

Într-una din zile, Grummer, fără a anunţa pe Algazy, luă roaba şi porni singur în căutare de cârpe şi arşice, dar la înapoiere, găsind din întâmplare şi câteva resturi de poeme, se făcu bolnav şi, sub plapomă, le mâncă singur pe furiş... Algazy, simţind, intră după el acolo cu intenţia sinceră de a-i face numai o uşoară morală, dar cu groază observă în stomacul lui Grummer că tot ce rămăsese bun în literatură fusese consumat şi digerat. (Urmuz 93-94)

[On a fine day Grummer took the barrow and set out alone to collect rags and ankle bones without telling Algazy. On the way back he chanced on to the left-overs of some poems which he stealthily ate all by himself under the covers pretending that he was sick... Algazy having caught on to this followed him inside sincerely intending to lecture him mildly, but he discovered to his horror that inside Grummer's stomach all that was good in literature that had been left over, had been eaten and digested.]

Many gladly digest good literature (however neglected). So why should one not use exclusive ingredients such as blue tit subconscious for cooking, as Sonja's recipe recommends?

Speaking of edibles, Urmuz's Ismaïl and Turnavitu (Ismaïl şi Turnavitu, 1922) begins:

Ismaïl este compus din ochi, favoriţi şi rochie şi se găseşte astăzi cu foarte mare greutate. 
Înainte vreme creştea şi în Grădina Botanică, iar mai târziu, graţie progresului ştiinţei moderne, s-a reuşit să se fabrice unul pe cale chimică, prin syntheză.

Ismaïl nu umblă niciodată singur. Poate fi găsit însă pe la ora $51 / 2$ dimineaţa, rătăcind în zig-zag pe strada Arionoaiei, însoţit find de un viezure de care se află strâns legat cu odgon de vapor şi pe care în timpul nopţii îl mănâncă crud şi viu, după ce mai întâi i-a rupt urechile şi a stors pe el puţină lămâie... Alţi viezuri mai cultivă Ismail în o pepinieră situată în fundul unei gropi din Dobrogea, unde îi întreţine până ce au împlinit vârsta de 16 ani şi au căpătat forme mai pline, când, la adăpost de orice răspundere penală, îi necinsteşte rând pe rând şi fără pic de mustrare de cuget. (Urmuz 58)

[Ismaïl is made up of eyes, whiskers and an evening gown and nowadays he is in very short supply in the market.

Formerly, he used to grow in the Botanical Garden too, and later on, thanks to the progress of modern science, one has been produced chemically, ${ }^{11}$ through synthèse.

Ismail never walks alone. Yet one may find him at about half past five a.m., wandering in zigzag along Arionoaia Street, accompanied by a badger, to which he is closely bound with a ship's cable and which during the night he eats, raw and alive, having first pulled off its ears and squeezed a little lemon on it... Other badgers are cultivated by Ismail in a nursery situated at the bottom of a pit in Dobruja, where he supports them until they reach the age of 16 and become more shapely, when, exonerated from any personal responsibility, he deflowers them in turn and without the least compunction.]

Strangely enough, both Ismaïl and "Aunt Mioara" - although Sonja was unfamiliar with Urmuz - indicate the violence, physical or otherwise, lodged at the very core of the absurd. Urmuz's character eats the badger, his perambulation companion, alive, after first tearing off its ears, as one removes gills. Worse yet, before making them into his à la carte, Ismaill consumes the badgers sexually, albeit surreptitiously, for fear of legal accountability. Sonja's recipe instructs readers to $c u t-$ a typical violent culinary action, as is crushing the ingredients - a leg of the blind pigeon. The same readers/users should also talk with the blue tit 
subconscious about Gregory's hand, alienated as it is from Gregory as integer ingredient. (Could Gregory be the avatar of Ismail's anonymous badger, and the hand of the former isomorphic with the badger's ears?)

One relates strangeness, theoretically, to the uncanny Sigmund Freud mentions in Totem und Tabu (1912-1913) and elaborates on in "Das Unheimliche" (1919). ${ }^{12}$ Freud's uncanny (unheimlich) names the terror, associated with the return of the repressed, generated by that which for a long while has appeared to be familiar (heimlich). To apply Freud's concept to the texts of Urmuz or Sonja, the uncanny originates in what I would call a breach of consciousness: the fresh look at the world as if encountering it for the first time, a world in which everything coexists beyond necessary rapports. On such an occasion, one can intuit the fundamental uncanniness of the world beneath any apparent familiarity bestowed by our traditional definitions, viz., by the categorial grid we impose on the world to make it intelligible.

Nonetheless, neither Urmuz nor Sonja intimates that the defamiliarising perception of the everyday elicits fear, let alone terror. Their distancing from Freud's unheimlich may owe in part to the ludic tenor of their texts. Playful defamiliarisation fosters enough mental relaxation to defuse any emerging threat and euphemise it as merely an uncanny case. Thus, we ignore the explicit violence inhering in Ismail's dealings with his badgers because of the funny lemon squeezing on an inert, lettuce-like creature. To such ludic mystification of violence also contributes the reception of the text as one for the page, not for the stage. Similarly, we overlook the violence implicit in the crushing of three blue tit eyes to blend in with Sonja's other ingredients, at least because of her amusing terms. What could the "ceve plângăcioase" (crying ceve) be: onions ("cepe"), which make one cry; pork shoulder ("cefe de porc"); or merely a comic coinage? What about the equally unintelligible, untranslatable "piersicăruri de caise negre" (approximately, "peach-dish of black apricots")? Are they the latest fashionable confiture or rather a dish ${ }^{13}$ unto its own to go along with (or on the side of) the crying "ceve" (pork shoulder)? 
Mutatis mutandis, violence looms large - and deliberately so - in the theatre of cruelty theorised by Antonin Artaud ${ }^{14}$ and practised on the Grand Guignol stage or experimented with by Luis Buñuel in Un chien andalou (1929). ${ }^{15}$ The rationale behind such extremes of cruelty (albeit, luckily, mere sleight of hand, although no less violent conceptually) is avowedly to defamiliarise at once the tradition of realist theatre and our bland perception of life.

The other term I have used, "the absurd," belongs to literary jargon. In 1961, Martin Esslin lumped the plays of Eugène Ionesco, Samuel Beckett, Harold Pinter, Arthur Adamov and Edward Albee as the "theatre of the absurd." Such theatre, Esslin argues, is testament to the "metaphysical anguish of the absurdity of the human condition" (xix). Fifty years later, Michael Bennett's Reassessing the Theatre of the Absurd (2011) offered a fresh perspective on the absurd. Esslin's concept is inaccurate, Bennett contends, on two counts: to define the absurd, Esslin (xix) used a "mistranslate[d] and miscontextualise[d]" quotation from Ionesco (Bennett 2); furthermore, like his contemporaries, Esslin misconstrued Camus as an existentialist (Bennett 2). ${ }^{16}$ Esslin's absurd plays become, for Bennett, "parabolic drama" (2). "[E]thical parables that force the audience to make life meaningful" in a world of absurd situations, they "rather[] revolt against existentialism (2).

What is left of the absurd? Nihilism for nihilism's sake? Radical scepticism? The nonsense ${ }^{17}$ cultivated by the Dadaists and Surrealists (and by Ionesco later), meant to free language from the constraints of logic and rationalism to experiment with it? ${ }^{18}$ Mere nonsense - one distinct from any artistic/theoretical manifesto, hence apparently spontaneous and involuntary? Another face of stultitia (foolishness), the butt of Jonathan Swift in part three of Gulliver's Travels (1726) and of Ion Creangă in "Story: Human Folly" ("Poveste (Prostia omenească)," 1874)? Kafkaesque surrealism entwined with political arbitrariness? A notion that defines a ridiculous, ${ }^{19}$ stultifying situation, which nevertheless does not render an individual's existence, let alone existence per se, ridiculous? 
In the absence of uncontroversial concepts, I will use here the term (the) absurd to refer to fictional or non-fictional cases that seem to be irrational (albeit not in a psychiatric sense), even downright ridiculous; they offend our sense of what is reasonably acceptable. The term uncanny, as in Freud, or, alternatively, strange, will name the outcome of perceiving certain everyday situations in a defamiliarising mode (sans Freud's terror).

I first heard Sonja's text at the hairdresser's. There is nothing intrinsically absurd, uncanny or comic about such circumstances, but rather fitting. Not Sonja read it to us (as she was not present), but her mother, off her (the mother's) smartphone. Sonja's is a composition written by a fourth grader (now an undergraduate student) in response to an ordinary school assignment. Urmuz would laugh his head off.

My intertextual reading of the "scribblings" of a then barely eleven-year-old child, which, moreover, Sonja repudiates now, bears on how I regard the absurd. Let's, therefore, examine such intertextuality further. Her family cannot confirm whether or not Sonja knew Lewis Carroll's famous "absurd" ${ }^{20}$ story Alice's Adventures in Wonderland (1865). ${ }^{21}$ Nor could she have been familiar with either Urmuz's texts or Macbeth, not typically regarded as children's literature. Yet Sonja may have heard/read texts far more suitable for her age (for instance, fairy tales) which included a recipe or menu of a witch's foodstuffs. In fact, the recipe as discursive structure may have sounded familiar to Sonja from her everyday experience. In many families, a girl is encouraged to play at cooking and/or to help her mother in the kitchen. Her socialisation, therefore, prepares her for patriarchally decreed gender roles, as if she were the only individual who ate, but especially whose duty were to be everyone else's care-giver. Speaking of the absurd, that category so resistant to reasonable definition...

Although Sonja may not have encountered the playful absurd and satire concealed behind the court cards of Alice's Adventures in Wonderland, Carroll is a landmark on the route to the absurd. Should we consider only the famous tea party at the Mad Hatter's 
place (chapter 7), we may begin to realise why some people sometimes point their finger - and poke fun - at the arbitrariness of rules and regulations, including manners, which, culture- and agedependent, may verge on hypocrisy or even the absurd. A yet unregimented child will cry, unceremoniously, "but the emperor is naked," unafraid of being branded foolish. Or a Mad Hatter will rudely tell a girl stranded in Wonderland: "Your hair wants cutting" (Carroll 75). Precisely the latter context signals the incongruity of the Hatter's "Do you mean that you think you can find out...? [...] Then you should say what you mean" and Alice's "I do [...], at least [...] I mean what I say" (Carroll 75-76). The latter two structures, as Alice learns via the absurd, indicate the relationship between self and society as encoded by rules of polite as well as semantically correct exchange. The brave or the reckless will defy either rule set. They may start, for instance, to beat time irregularly to show they can beat anything and anyone as they please, and not only in the music class - on pain of being accused, as was the Hatter, that they have murdered time. Should we wonder why Time is mad at the Hatter; why it is always tea-time at the latter's place, to everyone's ennui (Carroll 78-80)? Unsurprisingly, in the wake of his (inadvertent) quarrel with Time, the Mad Hatter (mis)takes the poor Dormouse for a biscuit to be dipped into the tea (or be shoved down into the teapot) during their endless tea routine. Will the Hatter also nibble from his companion the Dormouse, like Urmuz's Ismail from his companion the badger?

Who would have thought that Ismail might have had a precursor - I cannot claim a model - as famous as Carroll's Mad Hatter? Or who would have contended, save Humpty Dumpty from Through the Looking-Glass (1872), chapter 6, that words "mean[] just what I choose [them] to mean - neither more nor less" (Carroll 214)? For him, meaning concerns "which is to be master" (214), as in Genesis (2.18-23; 3.20). If la loi, c'est moi with respect to socially applied semantics in the service of power relations, then anything that sounds pleasing may become an ingredient in a pie (on a bench, if not in the sky). Especially the blue tit subconscious, with all that is seething in it... 
With Carroll we laugh - when we can. His writings' absurd, intellectual in nature, is predicated on scrutinising the ultracorrectness of logic, mathematics or semantics to turn it ultraopaque. Carroll thereby demystifies the predictability of formal principles as the strongest principle of reality: the chaos principle hence the absurd. This is the intersection point of Freud's uncanny, which defamiliarises the ordinary, at the risk of ushering in the terror of the real, and of the fundamental absurd of linguistic arbitrariness, of matching together a signifier and a signified in any natural language, which Ionesco unpacks. For what would become of playing with grammatical structures, such as shifting verb positions in "I see what I eat" or "I breathe when I sleep"? Perhaps the chaos of "I eat what I see" or "I sleep when I breathe," as the sage Mad Hatter and in his footsteps the drowsy Dormouse suggest to a perplexed Alice (Carroll 76)? What would happen if, trying to clarify which principles enable us to comprehend our world and which merely distort our understanding thereof, we introduced a new principle, meant to certify the validity of previous principles and of their operational logic, yet the principle might itself be suspected of distortion? Certainly, we could introduce one further principle to indubitably stipulate the validity... But what if ...? ${ }^{22}$ The problem and its solution come from Carroll, alias Charles Lutwidge Dodgson, the don teaching mathematics at Christ College, Oxford, and delighting in the arcane reasoning of logic.

We laugh with Urmuz too - as much as we do when we contemplate Pablo Picasso's cubism. Urmuz's absurd sounds formal and pretentious. It analyses and reconstitutes reality in arbitrary fashion, contorts and squeezes the concrete to render it abstract, almost uncanny. What creature - produced through "synthèse"! - would Ismaill, the raw-badger gourmet, be; or Algazy, the poetry gourmet? Stamate's table on what kind of probability calculus stands?

Sometimes, the absurd saturates texts all the way to the characters' manners. Regarding the latter, the absurd may conceivably start, in Romanian culture, with the dog days which melt down feeble minds. In I. L. Caragiale (1852-1912), the absurd 
is gentle, quasi-imperceptible, certainly much more easily bearable than the dog days it is blamed on ("Căldură mare" ["Dog Days"], 18 May 1901). ${ }^{23}$ Yet what if the absurd - only in fiction? - starts with the absence of urban planning but assiduous building? Or else why would the street have been misaligned in spring (so that the houses have a three-corner drawing-room that appears to be cut en biais), only to be realigned in autumn ("Caut casă..." ["House Wanted..."], 17 Sept. 1899; in Momente şi schiţe ${ }^{24}$ 1:87)? The craze of cyclic house renting by tenants and renting out by owners so that the latter can themselves rent a new house, every St George's and St Demetrios's Days ("De închiriat" ["For Rent"], 28 Apr. 1900), becomes a debased Ahasuerus rite. Yet, this estate game superimposed with the mythology of meliorism, or rather the fad of emulation, allows us to glimpse the absurd core of what Caragiale derides. Blame it on the houses in fin de siècle Bucharest!

Or shall we blame it on those responsible for the street misalignment, whoever they may have been - the head architect, the mayor or the prefect? Most likely a jackass in a position of authority, to paraphrase Grigore Alexandrescu (1810-1885) in "Boul şi viţelul" (literally, "The Ox and the Calf," 1838). ${ }^{25}$ Indeed, how does one get promoted professionally, socially and/or politically, especially when one is "an ordinary jackass" (approximation of Alexandrescu's "un bou ca toţi boii," line 1)? Perhaps through lucky chance (line 2), viz., when one is fortunate enough to get a position newly vacated/established? If so, then why does that line start "Nowadays," merely for prosody's sake? To make sense of the underpinnings of promotion as satirised in Alexandrescu's fable ${ }^{26}$ perhaps we should return to Caragiale. The ridiculous, mean political plots which The Lost Letter ( $O$ scrisoare pierdută, $1884 / 1889$ ) satirises are outclassed - artistically - only by the characters' absurd political rhetoric: "Either revision - agreed! but no changes to be effected; or no revision - agreed! but then some changes to be effected, namely of cardinal issues" ("Din două una, daţi-mi voie: ori să se revizuiască, primesc! dar să nu se schimbe nimica; ori să nu se revizuiască, primesc! dar atunci să se 
schimbe pe ici pe colo, şi anume în punctele esenţiale"; III.i, p. 171; my trans. ${ }^{27}$ ). Ave, Farfuridi, mon semblable, mon frère!

Irrefutable logic, noble political, even patriotic, ideals, all most likely acquired ... at school? Indeed, does not Caragiale's satire of manners lampoon education itself for its absurdities? Getting one's baccalaureate diploma may be jeopardised by failing Ethics, which would postpone enrolment in the Law School for a year ("Bacalaureat" ["Baccalaureate Examination"], 15 Sept. 1900). Elsewhere, failing Latin could produce similar effects ("Lanţul slăbiciunilor" ["Chain of Friendship"], 24 June 1901). No different is the humiliating "persecution" $(M \& s$ 2:236) of the middle-class student, who systematically fails to get the first prize with honours because of a minor difference between his results and those of an impoverished widow's son ("Premiul întâi" ["First Prize"], 3 July 1900). Anguished by her son's "persecution," the mother succumbs to the endless chain of friendship, whether heterosexual or otherwise. Flirtation, friendships, nepotism (or, alternatively, the authorities' pressure) - and there the student passes his (sic) exam (or gets the first prize with honours)! How else to pass? Only rarely does one encounter, in Caragiale, a teacher like Pricupescu, who, on the verge of retirement, makes no concessions in exams to his students by virtue of their fathers' portfolio ("Dascăl prost" ["Sucker Teacher"], 16 June 1900).

Absurd or tragic or tragi-comic is it when we notice something else about our educational system? It may sometimes strike us, as it did Creangă (1837-1889) too, that "the teacher, who would himself [sic] wonder at his being a teacher, used to say: 'take it from here down to here" (Memories of My Boyhood 54). Creangă continues in one breath: "as I believe they still do in some places to this very day" (54). ${ }^{28}$ Notwithstanding, the educational system is not a complete fiasco. So proves Caragiale in his fable "Boul şi Viţelul" ("The Ox and the Calf," 1909), a pastiche of Alexandrescu's namesake fable, written in response to the Peasants' Uprising in 1907. School transforms the title's calf qua young jackass into an expert: 
Învăţă la şcoală cartea de citire

Şi ajunse boul un bou învăţat. [...]

Printr-o bună şcoală, rafinezi natura.

Din viţel poţi scoate un bou eminent.

[Learning his primer at school

The jackass became a learned jackass.

Good education can refine gross nature,

And a green jackass can turn an eminent one.] (Caragiale, "Boul şi

Viţelul" ["The Ox and the Calf"], lines 3-4, 7-8; my trans.)

Indeed, education is golden.

What Caragiale's Cănuţă experiences at school ("Cănuţă, om sucit" ["Cănuţă, Wayward Chap"], 20 Dec. 1897 and 5 Jan. 1898) may suggest yet another educational issue. The orphan whom his grandmother enrols in primary school becomes the teacher's lightning rod. One day the teacher comes "angry" to school; the next one, "angrier still"; the third day, downright "mad" (in Kir Ianulea 59-60). ${ }^{29}$ So, Cănuță, just answer this quiz quickly (KI 5960): how many rulers had the Romanian province, ${ }^{30}$ "moron," "fool," "dimwit"? How many types of complex numbers are there, "dunce," "jackass," "donkey," "meathead"? How many rivers are there in Europe, "scoundrel"? (Until then, the scoundrel had been desperately counting the other two sets.) Who would not go to hell to count them - and never return to school (60)? The teacher feigns puzzlement on seeing such a "wayward child" whom "you ask one thing" but who "will answer something else," as he explains to the confounded grandmother (60). Indeed, wayward chap! Cănuţă at school? Perhaps...?

But let us not be over-critical. Not all of Caragiale's learned characters are as puffed up as Mariu Chicoş Rostogan ("Un pedagog de şcoală nouă" ["A New School Pedagogue"], 1893), the multilingual, self-styled "absolute" pedagogue ( $M \& s$ 1:36). Despite the novelty of his inductive teaching methods, he complains, his pupils are but "dolts" ("prostovan[i]," 1:37, 1:40), or, as he calls them in "Emulation" ("Emulaţiune," 19 May 1900), "Levantine scoundrels" wanting "application" ("loaze levantine" "fără aplicaţiune," M\&s 2:211, 2:213). On the contrary, some are 
intellectuals; originally discreet, or rather loath to mingle with ignoramuses at the café, later they assume the apostolic mission to disseminate knowledge to the masses ("Intelectualii" ["The Intellectuals"], 8 Oct. 1899). Others, whom Caragiale identifies as a category unto its own, are best embodied by the savant, one of the generic "fickle" ("Moftangii: Savantul" ["The Fickle: The Savant"], 19 Feb. 1893). The savant raises human folly as derided by Creangă to the rarefied scholarly heights of the academy Gulliver's Travels derides. Caragiale's savant will be the director of a national research institute - which, if not yet founded, should certainly be - whose object of research is public lighting with fireflies. Until the project of "domesticating, breeding and educating the fireflies" ( $M \& s$ 2:136) takes off, he needs financial support for study trips to both hemispheres $(2: 136)$ to learn from other nations. Wouldn't even fireflies laugh at such projects? Yet not at Caragiale's savant, but at a Romanian architect, Victor Gheorghe Ştefănescu. In the early 1900s, Ştefănescu received financial support for study trips abroad to enlighten him how to enlarge Constanţa's mosque (now Carol I Mosque), in response to the royal commission. The trip led him from the Hagia Sophia to the Taj Mahal for models! ${ }^{31}$ There's a thorough professional indeed!

It is strange (if not quite absurd) how my argument has shifted from school to savants to religion! Speaking of which, do we dare, in 2019, to broach the absurd even where we have never learned to suspect it: in the religiously fostered obsessive xenophobia which "An Easter Light" ("O făclie de Paşte," 1 Aug. 1889) illustrates? I do not mean to argue that Caragiale's short story either proves or disproves any allegation of his antisemitism, just as I would not do concerning William Shakespeare's The Merchant of Venice. Caragiale's Jewish protagonist might become, has he not already done so, the object of psychiatric interest, for instance to study representations of obsessive-compulsive disorders. What is absurd - as well as dangerous - is the persistence of the offending term for Jews, "jidan"/"jidov" [Yid] (KI 5, 7, 8, 10, 18), in the twenty-first century. There is here an abiding belief that the Jews 
practise various abominations such as allegedly baking human blood pie $^{32}$ - a recipe unlike Sonja's. Should we blame such "persistence of memory" on our human incapacity to distinguish between racist or xenophobic anecdotes and biblical stories, on the one hand, and historical vicissitudes or socio-culturally instilled intolerance, on the other?

What is truly absurd is how sociopolitical, civic, educational or moral situations satirised by the likes of Caragiale seem to be fixtures in our non-fictional social world, as if what is descriptive there had been mistaken for prescriptive. Would this be symptomatic of an absurdist vein in our national being - or, worse, in the human being - rather than of Caragiale's heightened sense of his contemporary world's absurd workings?

Mine is not a philosophico-critical excursus aiming to proffer, at the very least, enough examples from texts by Caragiale, Urmuz, Ionesco, Carroll or Borges, and robust theoretical-critical approaches to the absurd, to support an absurdist argument in connection with my previous query. Nor have I undertaken an archaeology of our everyday absurd, lest I run into the tragi-comic, not just the absurd. How would I classify the case of Romanian academics in the 2010s, who have to report (and quantify) yearly, biennially and in every way their research activity, yet subsequently some of them are also charged with checking and centralising the individual data? Or the bureaucratic international classification of scholarly output through the grid of ISI publication?

This latter case reminds me, through an uncanny association of ideas, of a scene in The Lesson (La Leçon, 1951) by Ionesco (1909-1994). Angered by his Pupil, the Professor names incommensurate teaching positions to show her incapable of "teach[ing] a course in a polytechnical school ... or the primary grades" (Four Plays 58). I am more interested, however, in the play's overall argument about partial or total doctorates (sic!) awarded overnight, which suggests the educational system may easily lapse into dangerous bureaucratic absurdity: 
PUPIL: [...] My parents are fairly rich, I'm lucky. They can help me in my work, help me in my very advanced studies (à faire des études très supérieures).

PROFESSOR: And you wish to qualify for...?

PUPIL: Just as soon as possible, for the first doctor's orals. They're in three weeks' time.

PROFESSOR: You already have your high school diploma, if you'll pardon the question?

PUPIL: Yes, Professor, I have my science diploma and my arts diploma too.

PROFESSOR: Ah, you're very far advanced, even perhaps too advanced for your age. And which doctorate do you wish to qualify for? In the physical sciences or in moral philosophy?

PUPIL: My parents are very much hoping - if you think it will be possible in such a short time - they very much hope that I can qualify for the total doctorate (ils voudraient bien que je passe mon doctorat total). [...]

PROFESSOR: I hear that you will not be able to qualify for the total doctor's orals (Je crains que vous ne puissiez vous présenter au concours $d u$ doctorat total)... [...] We will try to prepare you at least for the partial doctorate (Nous tâcherons de vous préparer pour le passage, au mains, du doctorat partiel)... (Ionesco, Four Plays 49, 59; La Leçon 94-95, 116)

Whilst taxing the Pupil with paying no attention, the Professor boasts about his own achievements: "it is not I who is going to qualify for the total doctor's orals ... I passed mine a long time ago ... and I've won my total doctorate too ... and my supertotal diploma"33 (Four Plays 71). Quite an inflation of degrees and honours! Too bad Jacques Derrida used Rousseau's Emile instead of Ionesco's "super-total diploma" scene to theorise the supplement as that whose presence invalidates claims to totality by the supplemented entity!

Ionesco returns polemically to partial scholastic degrees in The Gap (La Lacune, 1965). The famed (if anonymous) French Academician, invited to lecture at universities worldwide, nearly has his baccalaureate diploma: he neglected to take the second part of his baccalaureate examinations. Challenged by detractors that the 
omission virtually invalidates all his subsequent degrees, the Academician decides to sit for the missing exams - which he fails with flying colours. Enemies' machinations, decidedly, he insists even when confronted with indubitable evidence: his own paper. How could he possibly admit his answers' inadequacy? Ionesco's is here another kind of baccalaureate examination - of honoris causa awardees who are actually unschooled - than the one described by Caragiale. The absurd of The Gap has by now waxed cankerous through "repeatability" from one text to another, as well as from the text to the world at large and/or vice versa. I wonder, though, how the chain of friendship worked in the Academician's case, for innocuous flirtation or being pub pals cannot have sufficed. The Gap anticipates by a few years the collection of honorific titles, especially honoris causa awards, by two Romanian self-proclaimed "academicians" with hardly any education yet brandishing their party membership card and supreme function in the state as their scholastic credit. Their names, not worth mentioning, are familiar to middle-aged Romanians who watched on TV, belatedly, their execution. (Might there be some other such doctorates and honours around, if disseminated nationwide of late?) Erratum: horroris causa...

\section{****}

Lest I may seem to have but played at the absurd, I ought to return to the absurd and/or the uncanniness of the above-mentioned writings. What is the differentia specifica between satire and the absurd? When is the sociopolitical absurd full-fledged "absurd" rather than a misused, toned-down term for sociopolitical inanity? I would distinguish two broad categories, which may nevertheless often overlap in part. On the one hand, there is the "pure" absurd of Urmuz (and Sonja); of Caragiale in "Dog Days" ("Căldură mare"); of Ionesco in English Self-Taught (Englezeşte fără profesor, the early Romanian version of La Cantatrice chauve); or of Carroll in Alice's Adventures in Wonderland when the Mad Hatter et co. digress incredibly logically (for indeed, "I get what I like" is not the 
same as "I like what I get"). This is a type of nonsense generated by extreme playing with linguistic rules or by defamiliarisation (akin to Freud's uncanny and sometimes perhaps to the fantastic). Yet such purity of the absurd is rather deceptive. Caragiale's "For Rent" ("De închiriat"), for instance, strikes me as dabbling equally in the absurd and in satire: mocking socially compulsive routine for the sake of keeping up with the Joneses points to the social absurd (nearly a social void). On the other hand, sociopolitical satire and especially the satire of manners are predicated on a kind of "human folly" nonsense seen as infecting the polity. The irrational (in the pragmatic, not psychiatric, sense) underpins such socially damaging conduct; it names the irrationality of bureaucracy and of working with yet another "jackass in a position of authority" ("bou în post mare") - our everyday absurd. Strangely, when I studied Alexandrescu's fable, the professor never mentioned Caragiale's namesake pastiche. Notwithstanding, I can recall my disheartening illumination, an "effect of reality" (Freud's unheimlich, not Roland Barthes's effet de réel), on re-encountering the phrase "un bou în post mare" as an undergraduate. My response suggests that satire may create effects of the absurd or the uncanny, not just of the ridiculous, although often merely in the sense of articulating one's disbelief: how could possibly anything like it happen? The arbitrariness of social relations and hierarchies does not differ fundamentally from linguistic arbitrariness, as Humpty-Dumpty, with his authority over words, demonstrates or from epistemic arbitrariness, as both Urmuz and the-Chinese-encyclopaedia Borges demonstrate. Arbitrariness-uncanniness-the absurd: a random list. A fresh or frightened or scornfully alienated/-ing look at life.

Whatever baking powder may Sonja - or perhaps Aunt Maria - have used to have revealed so much from the dwarf blue tit subconscious? Uncanny indeed, if not absurd... 


\section{Notes:}

${ }^{1}$ Manuscript: obliteration of the early spelling of the name Herda. The position of the footnote number before or after a word indicates alterations in her text by the author herself or, if necessary, layout specifics. I have retained the manuscript's layout throughout.

${ }^{2}$ The author has requested me to call her "Sonja" since she "is ashamed of what she wrote."

${ }^{3}$ Manuscript: the beginning of the second page.

${ }^{4}$ The photography angle obliterates the line end, hence the punctuation too.

${ }^{5}$ Manuscript: the beginning of the third page.

${ }^{6}$ Manuscript: erasure of şi ("and").

${ }^{7}$ Manuscript: erasure of băgaţi-le la cu ("place them into the ov...").

${ }^{8}$ Untranslatable pun: the phrase "a se coace la soare" ("to lie in the sun"; alternatively, "to be hot" in the scorching sun) uses reflexively the otherwise transitive verb "a coace" ("to bake").

${ }^{9}$ By this logic, "ardei slab" (literally, "lean pepper"), a jocular take on "ardei gras" (sweet pepper, literally "fat pepper"), becomes the hinge between ordinary ingredients (e.g. eggs), improbable ones (e.g. blue tit eyes) and imaginary ones (e.g. blue tit subconscious); Grigore/Gregory is a sui-generis category.

${ }^{10}$ I.e., Transylvania.

11 "One has been produced chemically" is my translation emendation.

${ }^{12}$ On Jung's own theorisation of the same, see Leader (261 and passim).

${ }^{13}$ The "-uri" ending affixed to "piersică" ("peach") marks the plural, hence my association with a dish or course (plural "mâncăruri"). Cooking will darken the appearance of ingredients, yet the apricots may also be an unheard-of (perhaps genetically modified) black sort.

${ }^{14}$ Unsurprisingly, the defamiliarisation technique - in its many guises relates the absurdist writers to Artaud through various forms of violence, whether at the level of structure or content, aimed at the everyday and familiar. On Artaud as one of the precursors of the absurdist playwrights, see Bennett in The Cambridge Introduction to Theatre and Literature of the Absurd, chapter 2.

${ }^{15}$ I cannot ignore either the gratuitous violence of the man preparing to split open the woman's eye, in the first scene, or the grim irony of the literal substitution of a scapegoat (a he-goat or maybe a donkey, as in the 
subsequent piano scene) whose eye is eventually split open. Why should the woman or animal be the target of male violence even in an absurd film?

${ }^{16}$ Bennett draws upon recent reassessments of Camus; see, for instance, Foley.

17 The concept of nonsense may be worth examining as a substitute for the absurd; see Tarantino and Caruso for the historicisation of nonsense with respect to both fiction and politics.

${ }^{18}$ I am drawing here loosely upon chapter 1 of Bennett's The Cambridge Introduction to Theatre and Literature of the Absurd, which reviews the concept of the absurd and its origins.

19 See the English usage of "absurd" for something regarded as "ridiculous" (Esslin xix).

${ }^{20}$ As Esslin rightly argues in The Theatre of the Absurd, chapter 7.

${ }^{21}$ Translated by Frida Papadache as Peripetiile Alisei în Tara Minunilor, Carroll's Wonderland had already been published by Editura Tineretului (Bucharest, 1965), and subsequently in the Biblioteca pentru toţi copiii (Library for All Children) series of Editura Ion Creangă (Bucharest 1976; 1987).

${ }^{22}$ I am drawing here upon "What the Tortoise Said to Achilles" (1894). Race finally finished, Carroll's text commences, the victor seats himself on the Tortoise's back. The vanquished, however, challenges Achilles to another kind of race: of logic. Since the warrior is famed for his swiftness rather than wits (although he is aware of the anachronism of their conversation about Euclid), he will jot down the Tortoise's observations in his notebook. This is how Achilles learns about the syllogism. Yet, no sooner has he understood the syllogism as some sort of mathematical transitivity, than the Tortoise undermines Achilles's syllogistic schooling by introducing doubt. A gap opens up between the user and the receiver of syllogisms. The former argues the truth value of the premises, conducive to a valid conclusion; the latter may accept this as a formal principle of syllogistic mechanics, but is not thereby compelled to believe in its veracity, viz., that the premises are necessarily true. Eureka, a new hypothesis may be introduced to state the truth value of the premises! Not to the Tortoise's satisfaction, though, for there is no necessary rapport between all these premises and the hypothesis to validate syllogistic mechanics. At this point, "the narrator, having pressing business at the Bank, was obliged to leave the happy pair, and did not again pass the spot 
until some months afterwards"; on his [sic] return, the two were debating the issue just as hotly - only, the notebook "appeared to be nearly full" (Carroll 1229).

${ }^{23}$ I mention exclusively the date when Caragiale first published the text, but not also the volume where it was first included subsequently.

${ }^{24}$ Henceforth abbreviated as $M \& s$, followed by volume number and page (or page range).

${ }^{25}$ Alexandrescu's "un bou în post mare" (line 5) uses the derogatory connotation of the noun "bou" ("ox") to name a stupid person, hence my "jackass" translation.

${ }^{26}$ Picture the calf, struck by his parvenu uncle's conduct and, moreover, being kept at the door (or rather at the gate), staring at the latter. (My image translates the Romanian saying "a se uita ca viţelul la poarta nouă," literally, "to stare like a calf at the new gate," which describes someone's stupid/incredulous looks when hearing something beyond one's comprehension.)

${ }^{27}$ The play's translation, published by Lawrence and Wishart (1956), has been unavailable to me.

28 "[P]rofesorul, care şi el se mira cum a ajuns profesor, zicea: 'luaţi de ici până ici', cum mi se pare că se mai face pe une locuri şi astăzi" (Creangă 214).

${ }^{29}$ Henceforth abbreviated as $K I$.

30 The confusing "ţara românească" spelling may refer to "Ţara Românească" (Wallachia), all Romanian provinces irrespective of their names over time, or the newly edified Romania. In the first two cases, even towering Romanian historians such as the Giurescus would hesitate before answering, given the double "mandates" of certain rulers.

${ }^{31}$ Neither the data on the plaque of this historic monument nor the information displayed inside mentions the architect's study trip, which I read about, at the mosque entrance, in the early 2000s.

${ }^{32}$ The story has haunted the West since the twelfth century.

33 “"[C]e n'est pas moi qui me présente au concours du doctorat partiel... je l'ai passé, moi, il y a longtemps... y compris mon doctorat total... et mon diplôme supra-total..." (La Leçon 137). 


\section{Works Cited}

Alexandrescu, Grigore. Poezii. Proză (Poems. Prose Texts). Ed. Constantin Mohanu. Bucureşti: Ion Creangă, 1980. Print.

Bennett, Michael Y. Reassessing the Theatre of the Absurd: Camus, Beckett, Ionesco, Genet, and Pinter. New York: Palgrave Macmillan, 2011. Print.

---. The Cambridge Introduction to Theatre and Literature of the Absurd. Cambridge: Cambridge UP, 2015. Print.

Borges, Jorge Luis. "The Analytical Language of John Wilkins." Other Inquisitions 1937-1952. Trans. Ruth L. C. Simms. Austin: U of Texas P, 1993. 101-105. Print.

Buñuel, Louis, dir. Un chien andalou. Perf. Pierre Batcheff. 1929. Filmoteca Española, 1999-2003. DVD.

Caragiale, I. L. "Boul şi Viţelul" ("The Ox and the Calf"). Calendar literar şi artistic (The Literary and Artistic

Calendar). Bucureşti: Socec, 1909. 52-53. Digitised by Biblioteca digitală a Bucureştilor. Web. 30 May 2019.

--- Kir Ianulea. Bucureşti: Albatros, 1979. Print.

---. Momente şi schiţe (Short Pieces and Sketches). 2 vols. 2nd ed.

Bucureşti: Editura de stat pentru literatură şi artă, 1956. Print.

---. O scrisoare pierdută (The Lost Letter). In Teatru (Theatre). Ed.

Al. Rosetti and Liviu Călin. 3rd ed. Bucureşti: Editura Tineretului, 1965. Print.

Carroll, Lewis. The Complete Works of Lewis Carroll. Introduction Alexander Wollcot. New York: Vintage, 1976 (1936). Print.

Creangă, Ion. Amintiri din copilărie (Memories of My Boyhood). 1881-1892. Bucureşti-Chişinău: Litera International, 2002. Print.

---. Memories of My Boyhood. Trans. Ana Cartianu and R. C. Johnson. Selected Works of Ion Creangă and Mihai Eminescu. Ed. Kurt W. Treptow. Boulder: East European Monographs; Bucureşti: Minerva, 1991. 3-78. Print.

Esslin, Martin. The Theatre of the Absurd. New York: Anchor. 1961. Print. 
Foley, John. Albert Camus: From the Absurd to Revolt. London: Routledge, 2014. Print.

Freud, Sigmund. "The 'Uncanny"' (1919). The Standard Edition of the Complete Psychological Works of Sigmund Freud, Volume XVII (1917-1919): An Infantile Neurosis and Other Works. Ed. and trans. James Strachey. London: Hogarth P and the Institute of Psychoanalysis, 1955. 217-256. Print.

Ionesco, Eugène. The Gap. Trans. Rosette Lamont. Massachusetts Review (1969): 119-127. Print.

---. Four Plays: The Bald Soprano. The Lesson. Jack or the Submission. The Chairs. Trans. Donald M. Allen. New York: Grove P, 1958. Print.

---. La Cantatrice chauve - Anti-pièce. La Leçon-Drame comique. Collection Folio, 236. Paris: Gallimard, 1972. Print.

Leader, Carol. "Supervising the Uncanny: The Play within the Play." Journal of Analytical Psychology 60.5 (2015): 657-678. Web. 30 May 2019.

The New Oxford Annotated Bible: New Revised Standard Version with Apocrypha. Ed. Michael D. Coogan. 4th ed. New York: Oxford UP, 2010. Print.

Sonja. "Aunt Mioara at the Marketplace." School composition, 18 June 2010. Digital photograph, e-mail. 29 May 2019.

Tarantino, Elissabeta with Carlo Caruso, eds. Nonsense and Other Senses: Regulated Absurdity in Literature. Newcastle-uponTyne: Cambridge Scholars Publishing, 2009. Print.

Urmuz. Schiţe şi nuvele aproape ... futuriste (Almost ... Futuristic Sketches and Short Stories). Ed. Ion Pop. 2nd ed. Bucureşti: Biblioteca Bucureştilor, 2012. Web. 30 May 2019.

---. Pagini Bizare. Weird Pages. Trans. Stavros Deligiorgis. Bucureşti: Cartea Românească, 1985. Fragments available in Hot Black Ink: Modernist Idiosyncrasies: Urmuz-MateiuBlecher-Fondane-Naum. Ed. Erwin Kessler. Plural: Culture \& Civilization 3.19 (2003). Bucharest: The Romanian Cultural Web. 30 May 2019. 